University of Nebraska - Lincoln

DigitalCommons@University of Nebraska - Lincoln

Papers in the Earth and Atmospheric Sciences

Earth and Atmospheric Sciences, Department

2010

\title{
Climatic and Environmental Controls on the Occurrence and Distributions of Long Chain Alkenones in Lakes of the Interior United States
}

\author{
Jaime L. Toney \\ Brown University, jaime_toney@brown.edu \\ Yongsong Huang \\ Brown University, yongsong_haung@brown.edu \\ Sherilyn C. Fritz \\ University of Nebraska-Lincoln, sfritz2@unl.edu \\ Paul A. Baker \\ Duke University, pbaker@duke.edu \\ Eric Grimm \\ Illinois State Museum, Springfield, IL \\ See next page for additional authors
}

Follow this and additional works at: https://digitalcommons.unl.edu/geosciencefacpub

Part of the Earth Sciences Commons

Toney, Jaime L.; Huang, Yongsong; Fritz, Sherilyn C.; Baker, Paul A.; Grimm, Eric; and Nyren, Paul, "Climatic and Environmental Controls on the Occurrence and Distributions of Long Chain Alkenones in Lakes of the Interior United States" (2010). Papers in the Earth and Atmospheric Sciences. 124.

https://digitalcommons.unl.edu/geosciencefacpub/124

This Article is brought to you for free and open access by the Earth and Atmospheric Sciences, Department of at DigitalCommons@University of Nebraska - Lincoln. It has been accepted for inclusion in Papers in the Earth and Atmospheric Sciences by an authorized administrator of DigitalCommons@University of Nebraska - Lincoln. 


\section{Authors}

Jaime L. Toney, Yongsong Huang, Sherilyn C. Fritz, Paul A. Baker, Eric Grimm, and Paul Nyren 
Published in Geochimica et Cosmochimica Acta 74:5 (March 1, 2010), pp. 1563-1578; doi: 10.1016/j.gca.2009.11.021

Copyright () 2009 Elsevier Ltd. Used by permission. http://www.sciencedirect.com/science/journal/00167037

Submitted May 5, 2009; accepted November 16, 2009; published online November 22, 2009.

\title{
Climatic and Environmental Controls on the Occurrence and Distributions of Long Chain Alkenones in Lakes of the Interior United States
}

\author{
Jaime L. Toney, ${ }^{1}$ Yongsong Huang, ${ }^{1}$ Sherilyn C. Fritz, ${ }^{2}$ \\ Paul A. Baker, ${ }^{3}$ Eric Grimm, ${ }^{4}$ and Paul Nyren ${ }^{5}$ \\ 1. Department of Geological Sciences, Brown University, Providence, RI 02912, USA \\ 2. Department of Geosciences and School of Biological Sciences, \\ University of Nebraska-Lincoln, Lincoln, NE 68588-0340, USA \\ 3. Division of Earth and Ocean Sciences, Duke University, Durham, NC 27708, USA \\ 4. Illinois State Museum, 1101 East Ash Street, Springfield, IL 62703, USA \\ 5. Ag Experiment Station, Central Grasslands Research Extension Center, \\ North Dakota State University, Streeter, ND 58483, USA \\ Corresponding authors - J. L. Toney, tel 401 345-2196, email jaime_toney@brown.edu ; \\ Y. Huang, tel 401 863-3822, email yongsong_haung@brown.edu
}

\begin{abstract}
Long chain alkenones (LCA) are temperature-sensitive lipids with great potential for quantitative reconstruction of past continental climate. We conducted the first survey for alkenone biomarkers from 55 different lakes in the Northern Great Plains and Nebraska Sand Hills of the United States. Among those surveyed, we found 13 lakes that contain LCAs in the surface sediments. The highest concentrations of alkenones in sediments are found in cold (mean annual air temperature $\sim 11^{\circ} \mathrm{C}$ versus $17^{\circ} \mathrm{C}$ in our warmest sites), brackish to mesosaline (salinity $=8.5-9.7 \mathrm{~g} / \mathrm{L}$ ), and alkaline $(\mathrm{pH}=8.4-9.0)$ lakes with high concentrations of sodium and sulfate. The dynamics of stratification and nutrient availability also appear to play a role in LCA abundance, as early spring mixing promotes a bloom of alkenone-producing haptophytes. Four of the alkenone-containing sites contain the $\mathrm{C}_{37: 4}$ alkenone; however, we discovered an unprecedented lacustrine alkenone distribution in a cluster of lakes, with a total absence of $\mathrm{C}_{37: 4}$ alkenone. We attribute this unusual composition to a different haptophyte species and show that the sulfate:carbonate ratio may control the occurrence of these two distinct populations. We created a new in-situ temperature calibration for lacustrine sites that contain $\mathrm{C}_{37: 4}$ using a water-column calibration from Lake George, ND and show that $U_{37}^{K}$ is linearly correlated to lake water temperature $\left(R^{2}=0.74\right)$, but $U_{37}^{K^{\prime}}$ is not. A number of lakes contain an unidentified compound series that elutes close to the LCAs, highlighting the importance of routine GC-MS examination prior to using lacustrine LCAs for paleotemperature reconstructions.
\end{abstract}

\section{Introduction}

Long chain alkenones (LCAs), with carbon number ranging from $\mathrm{C}_{36}$ to $\mathrm{C}_{39}$, are a class of organic biomarkers well established for reconstruction of past sea surface temperatures (SSTs) (Brassell et al., 1986; Prahl and Wakeham, 1987) and surface ocean productivity (Moreno et al., 2004; Prahl et al., 2005). These biomarkers are produced by cos- mopolitan haptophyte algae (Emiliani huxleyii and Gephyrocapsa oceanica) in the ocean and can be preserved in sediments for millions of years (Volkman et al., 1980; Rontani et al., 1997; Sonzogni et al., 1997). The degree of unsaturation of $C_{37}$ alkenones $\left(U_{37}^{K}\right.$ or $U_{37}^{K^{\prime}}$ index) has been shown to be primarily a function of temperature in both core-top and culture experiments (Prahl et al., 1988; Marlowe et al., 1990; Rosell-Melé et al., 1995). Since its establishment, the 
alkenone unsaturation index has become an indispensable tool for paleoceanographic research (Müller et al., 1998; Lawrence et al., 2005).

LCAs also have been reported in lakes (Cranwell, 1985; Zink et al., 2001; Chu et al., 2005; D'Andrea and Huang, 2005; D'Andrea et al., 2006; Pearson et al., 2008) but they have not received significant attention by the continental paleoclimate community, primarily because (1) their occurrence is assumed to be rare; and (2) the identity of the algal species that produce lacustrine LCAs are not well-known and may be diverse (Coolen et al., 2004), thus potentially complicating interpretations of the unsaturation index as a function of temperature. Yet, there is a major need for new, quantitative paleotemperature proxies for continental sites, because the most common extant proxies either have geographically limited applicability (e.g., oxygen and hydrogen isotope ratios in ice cores) or are influenced by multiple climate or non-climate factors (e.g., speleothem $\delta^{18} \mathrm{O}$ is affected by temperature, precipitation, source water evaporation, water vapor trajectory, etc. and chironomids are potentially influenced by salinity, temperature, hydrology, and nutrients (Porinchu and MacDonald, 2003)). This is particularly important in the Northern Great Plains, where in-lake proxies for drought are well developed (i.e. diatomand ostracod-inferred salinity), but no temperature proxy exists for before the instrumental period. New techniques are being developed contemporaneously with the LCA temperature proxy, such as the distributions of glycerol dialkyl glycerol tetraethers (GDGTs) from bacteria (Weijers et al., 2007; Peterse et al., 2009) and archaea (Schouten et al., 2002). The $\mathrm{TEX}_{86}$ proxy has been used to reconstruct SST successfully (Schouten et al., 2002; Kim et al., 2008; Rueda et al., 2009), but appears to be only applicable in small number of large lakes (Powers et al., 2004; Tierney et al., 2008; Sinninghe Damasté et al., 2009). The MBT and CBT ratios based on GDGTs from soil bacteria (Weijers et al., 2007) are correlated to soil temperature and $\mathrm{pH}$, but their applicability in lakes is complicated by in-lake production of GDGTs with different distributions (Tierney and Russell, 2009). Therefore, the LCA temperature proxy, if fully developed, will be an important complement to existing tools for continental temperature reconstruction.

For LCAs to become a useful continental temperature proxy, the key environmental conditions controlling their occurrence and distribution need to be determined. To date, LCAs have been found in saline (D'Andrea and Huang, 2005; Liu et al., 2006; Pearson et al., 2008), and also freshwater lakes (Zink et al., 2001). Pearson et al. (2008) find that sodium sulfate-dominance is associated with the occurrence of LCAs in Spanish lakes, but LCAs also are found in carbonate-dominated lakes in Tibet and Greenland (Chu et al., 2005; D'Andrea and Huang, 2005). Thus, the factors that affect the presence or absence of alkenones are uncertain, and additional lake surveys are needed to understand the occurrence of alkenones in lakes.

Previous studies demonstrate a relationship between growth temperature and degree of unsaturation of sedimentary lacustrine LCAs (Zink et al., 2001; Chu et al., 2005; Liu et al., 2006; Pearson et al., 2008), but there are significant uncertainties in the alkenone-temperature calibration, presumably because individual lakes contain unique (although closely related) haptophyte species (Coolen et al., 2004; D'Andrea et al., 2006). Cultivation of lacustrine algae from individual lakes is one approach for establishing an appropriate calibration. This has proven successful when the haptophyte strain can be determined, for example
Figure 1. Map showing the location of investigated lakes sites. Numbers correspond to lakes listed in Table 1. Numbers enclosed by a square represent sites with alkenone presence in the modern lake sediments.

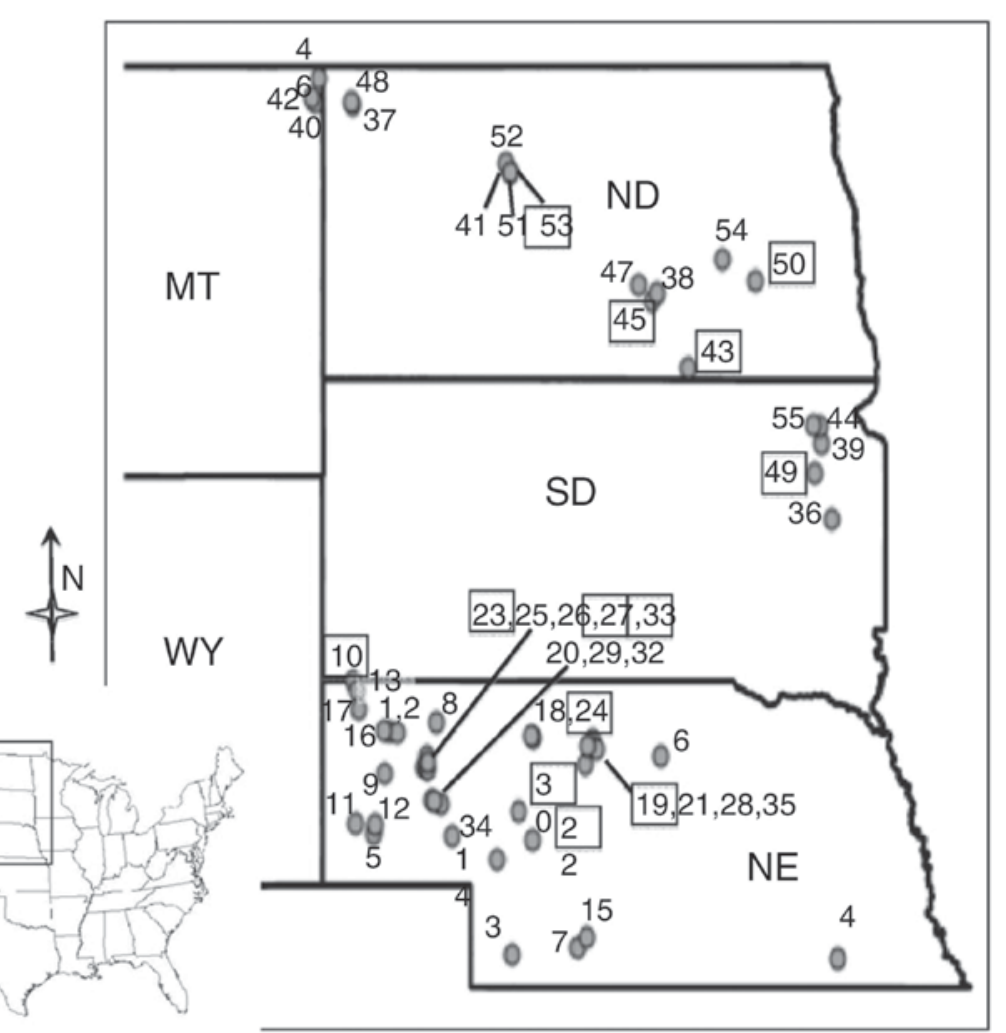




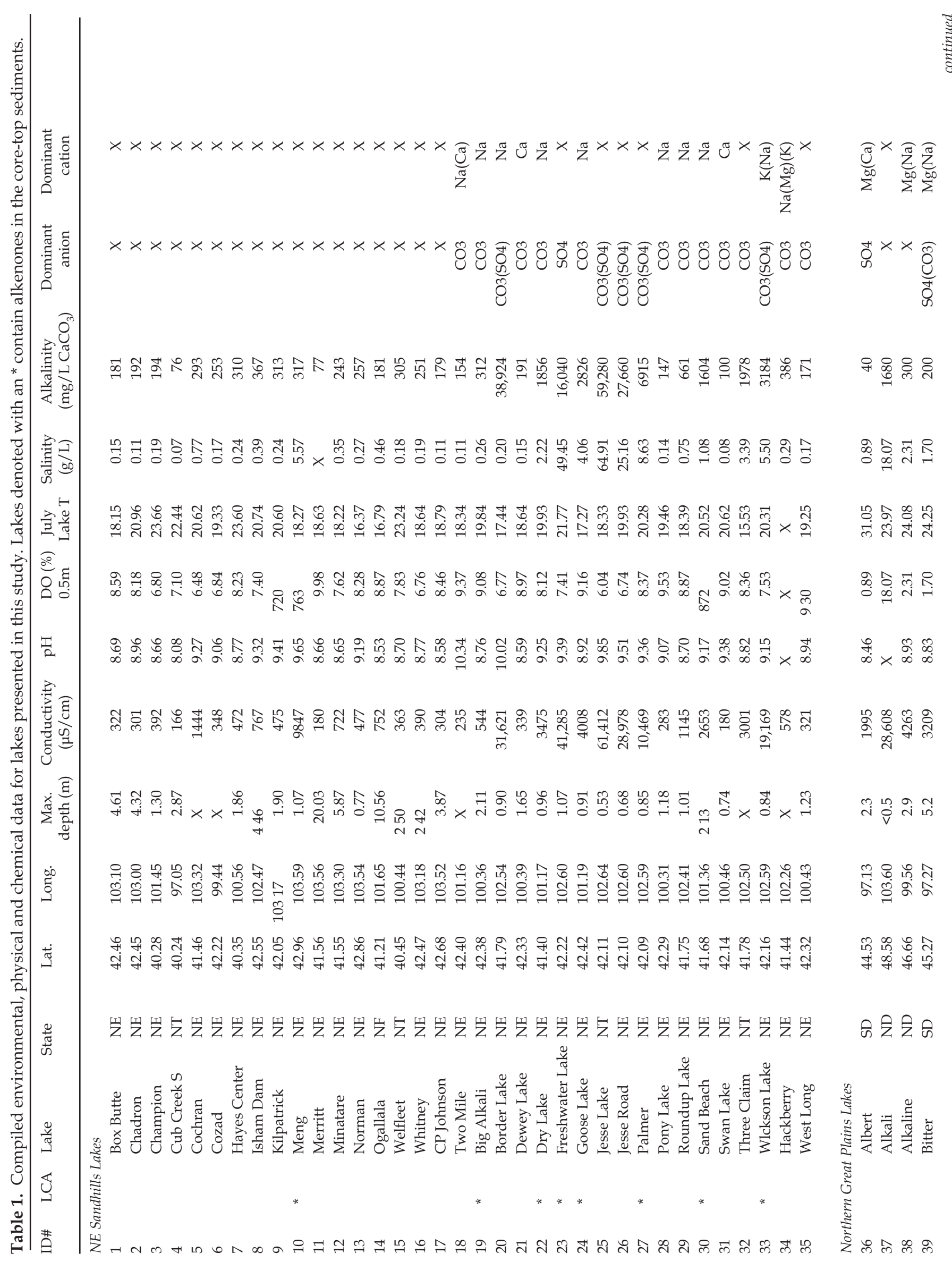


Sun et al. (2007) isolated a strain of C. lamellosa from Lake Xiarinur and create a culture-based calibration using the $U_{37}^{K^{\prime}}$ index. However, isolating and laboratory-cultivation alkenone-producing alga from other lakes has been challenging (Chu et al., 2005; Pearson et al., 2008). Thus, often calibrations for lake alkenones have been established using core-top sediments from transects of lake sites (e.g. Zink et al., 2001). This surface-sediment calibration approach makes implicit assumptions that all lakes contain the same haptophyte species or that different species have an equivalent relationship to temperature. Whether such assumptions are valid for all lakes requires additional testing. Theissen et al. (2005), on the other hand, used the alkenone unsaturation index from downcore samples as an indicator of relative temperature change without a specific calibration. The relative temperature change is of limited use in paleoclimatology, especially for regions that do not have tree ring, speleothem or other high-resolution datasets, such as the Great Plains, US.

The main objectives of the present study are to survey a large number $(n=55)$ of lakes in the North American interior, including the Northern Great Plains (NGP-ND, SD, and MT) and Nebraska Sand Hills (NE Sand Hills) (Figure 1) for LCAs and to explore the feasibility of a seasonal temperature reconstruction from the time alkenone-producers bloom in this region. We also provide water-chemistry data and other geochemical and physical information from the lakes in order to constrain the environmental conditions that favor the occurrence of LCA-producing haptophytes. To date, LCAs have only been reported from one North American lake, Brush Lake in eastern Montana (Zink et al., 2001). We hypothesize that given alkenone-producers have been found from numerous saline lakes elsewhere (D'Andrea and Huang, 2005; Liu et al., 2006; Pearson et al., 2008) that LCAs are regionally widespread among saline lakes and common in the arid and semiarid regions of central North America. Rather than conducting a core-top calibration, we develop an in-situ calibration of the alkenone unsaturation index against water temperature using seasonal water-column filters, taking advantage of the water column temperature variation in a single stratified lake (Lake George, ND) where haptophytes occur.

\section{Methods}

\subsection{Field and sampling methods}

The sediments from the NGP lakes $(n=19)$ and NE Sand Hills $(n=34)$ were collected from the top $0-1 \mathrm{~cm}$ of a gravity surface corer (Figure 1). Water samples for the analysis of major cations and anions were collected from the surface $(0.5 \mathrm{~m})$ of the NGP lakes with a Van Dorn water sampler. Samples from the NE Sand Hills were part of a previous study on lake water chemistry (Bennett et al., 2007), and chemical measurements are not available for all lakes. Field measurement of surface water temperature, conductivity, salinity, $\mathrm{pH}$, and dissolved oxygen were made in July 2007 with a YSI hydrolab. In the laboratory sediment samples 
were frozen, freeze-dried, and processed for alkenone analysis (see below). Mean annual air temperature (MAAT) data were obtained for each site from the closest weather station (from weather.com). Water samples were collected from Lake George from May through July 2008 using a Van Dorn water sampler at the surface, $5 \mathrm{~m}$, and $10 \mathrm{~m}$ depth. One liter of water was filtered using a water vacuum filtration unit with combusted $\left(550^{\circ} \mathrm{C}\right)$ Whatman GF/F $0.7 \mu \mathrm{m}$, $47 \mathrm{~mm}$ glass filters. The available physical data and water column chemistry for all lakes are summarized in Table 1.

\subsection{Analytical methods}

Water samples were measured for major cation and anion concentrations at the University of Nebraska - Water Sciences Laboratory using atomic absorption spectrophotometry for cations and ion chromatography for anions. Each of the 55 freeze-dried sediments $(>2 \mathrm{~g})$ and 39 filter samples were homogenized and extracted with dichloromethane (DCM):methanol $(\mathrm{MeOH})(9: 1, \mathrm{v} / \mathrm{v})$ via an Accelerated Solvent Extractor ASE200 (Dionex). $\mathrm{C}_{36}$ n-alkane standard was added, and the total lipid extracts (TLEs) were run on a GC-FID for detection and quantification of alkenones using the internal standard. An Agilent DB-1 GC column $(60 \mathrm{~m} \times 320 \mu \mathrm{m} \times 0.10 \mu \mathrm{m})$ was used with the following temperature program: an initial temperature of $40{ }^{\circ} \mathrm{C}$ (hold $1 \mathrm{~min}$ ), $\operatorname{ramp} 30^{\circ} \mathrm{C} / \mathrm{min}$ to $290^{\circ} \mathrm{C}$ (hold $1 \mathrm{~min}$ ), ramp $5{ }^{\circ} \mathrm{C} / \mathrm{min}$ to $300^{\circ} \mathrm{C}$ (hold $0 \mathrm{~min}$ ) then $2{ }^{\circ} \mathrm{C} / \mathrm{min}$ to $325^{\circ} \mathrm{C}, \mathrm{GC}$ temperature program (hold $10 \mathrm{~min}$ ). The same temperature program was used on the GC-MS, and samples were run to confirm the identity of the alkenones using the known ion chromatograms and by comparison of mass spectral data with published data and GC retention times (de Leeuw et al., 1980; Marlowe et al., 1984). The final GC program described here is the result of many permutations of GC parameters, including the switch from helium as the carrier gas to hydrogen. As such we are able to resolve LCAs with $>4 \mu \mathrm{g}$ per sample (i.e. grams of dry sediment or liter of water). Alkenone standards of known temperature calibration are run on the GC-MS to ensure analytical precision $\left(<0.1^{\circ} \mathrm{C}\right)$.

Samples that contained peaks in the alkenone retention time region in the TLE phase were further separated into neutral and acid fractions by elution through a $\mathrm{LC}-\mathrm{NH}_{2} \mathrm{SPE}$ column using DCM:isopropyl alcohol (2:1, v/v), followed by ether with $4 \%$ acetic acid (v/v) (Huang et al., 2002). The neutral fraction was separated into the aliphatic (n-hexane), alkenone (DCM), alcohol (ethyl acetate:n-hexane 1:3, $\mathrm{v} / \mathrm{v})$, and polar $(\mathrm{MeOH})$ fractions using silica gel column chromatography. In order to remove alkenoates, alkenone fractions were then saponified in $5 \% \mathrm{KOH}$ in $\mathrm{MeOH}$ with $3 \%$ water and heated overnight at $75{ }^{\circ} \mathrm{C}$, acidified and extracted using $n$-hexane and rerun on the GC-FID.

A subsample from Hackberry Lake (ID 34, Table 1), NE that contains an unknown compound series (base peak $m / z$ 152) was hydrogenated by adding $5 \mathrm{ml}$ of $10 \% n$-hexane in ethyl acetate, $20 \mu \mathrm{l}$ of acetic acid, and a small amount of platinum oxide catalyst. Hydrogen gas was bubbled into the solution for $2 \mathrm{~h}$. The catalyst was filtered from solution, and the sample analyzed by GC-MS.

\subsection{Potential problems with alkenone identifications in lake sediments}

Alkenones generally display characteristic distribution of peak clusters of $\mathrm{C}_{37: 4}, \mathrm{C}_{37: 3}$ and $\mathrm{C}_{37: 2}$. These molecular distributions based on similar retention times in the GCFID are commonly taken as evidence of the presence of alkenones. However, in 7 alkenone-containing lakes (see asterisks in Table 2) as well as 12 of the NE Sand Hill lakes that do not contain alkenones, we found a series of compounds that display similar looking molecular distributions and that elute closely with alkenones in the GC-FID. Due to the similar GC retention times on the non-polar GC columns commonly used for alkenone analysis, these compounds that are not alkenones, can be easily mistaken for alkenones without examination by GC-MS.

The GC retention time and mass spectra for this structurally unknown series of compounds are shown in Figure 2ad. The $C_{36}$ compound with molecular weight $(\mathrm{m} / \mathrm{z}=516)$ elutes slightly after $(0.01 \mathrm{~min})$ the $\mathrm{C}_{37: 3}$ alkenone. Its mass spectrum shows a distinct $m / z 152$ base peak. The $C_{36: 1}$ compound has the molecular weight of 514 and is the one double-bond unsaturated form of the $\mathrm{C}_{36}$ compound, as demonstrated by hydrogenation of $\mathrm{C}_{36}$ (Figure 2b). Amazingly, the distributions of $\mathrm{C}_{36}$ and $\mathrm{C}_{36: 1}$ closely mimic the alkenone distributions (Figure 2d). The mass chromatogram of $m / z 152$ reveals a full series of compounds with $m / z 152$ as the base peak mass, and molecular weight ranging from 348 to 544 (Figure 2a). The 516 and 514 mass compounds elute in the $\mathrm{C}_{37: 4}$ and $\mathrm{C}_{37: 3}$ LCA range, while the 542 and 544 molecular ions elute with the $C_{39: 3}$ and $C_{39: 2}$ LCAs (Figure 2d). Different GC programs were tested to separate the compound from the alkenone peak; however, the retention time difference between these compounds and alkenones is within a hundredth of a minute. Therefore, the $m / z 152$ series of compounds are virtually impossible to distinguish from alkenones without GC-MS analysis. Hydrogenation of $\mathrm{C}_{36: 1}$ leads to the formation of $\mathrm{C}_{36: 0^{\prime}}$ which cannot be further hydrogenated using $\mathrm{H}_{2} / \mathrm{PtO}_{2}$,

Table 2. Sulfate and carbonate anion data and calculated ratios for alkenone-containing lakes. The two groups, NE Sandhills Lake and Northern Great Plains Lakes are significantly different $(p<0.05)$ (Data from previously unpublished fieldwork by Fritz.)

\begin{tabular}{lrrr}
\hline Lake & Carbonate $(\mathrm{mg} / \mathrm{L})$ & Sulfate $(\mathrm{mg} / \mathrm{L})$ & $\mathrm{SO} 4 / \mathrm{CO} 3$ \\
\hline NE Sandhills Lakes & & & \\
Big Alkali & 209 & 3 & 0.01 \\
Dry Lake & 1240 & 49 & 0.04 \\
Freshwater Lake & 10,713 & 27,783 & 2.59 \\
Goose Lake & 1887 & 84 & 0.04 \\
Palmer & 4618 & 692 & 0.15 \\
Sand Beach & 1071 & 10 & 0.01 \\
Wickson Lake & 2127 & 931 & 0.44 \\
& & & \\
Northern Great Plains Lakes & & & \\
George & 346 & 12,210 & 35.25 \\
Medicine & 245 & 28,680 & 117.06 \\
Moon & 73 & 2541 & 34.67 \\
Skoal & 277 & 8955 & 32.34 \\
Coldwater & 125.1 & 1898 & 15.17 \\
Brush & 281.8 & 2304 & 8.18 \\
\hline
\end{tabular}


(a)

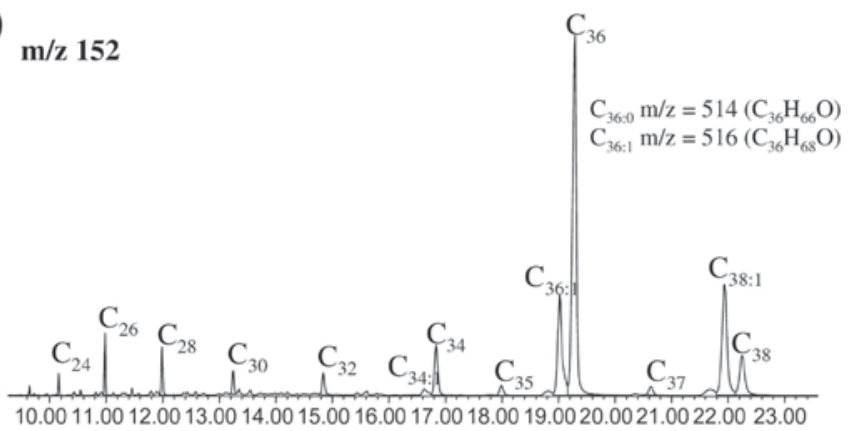

(c)

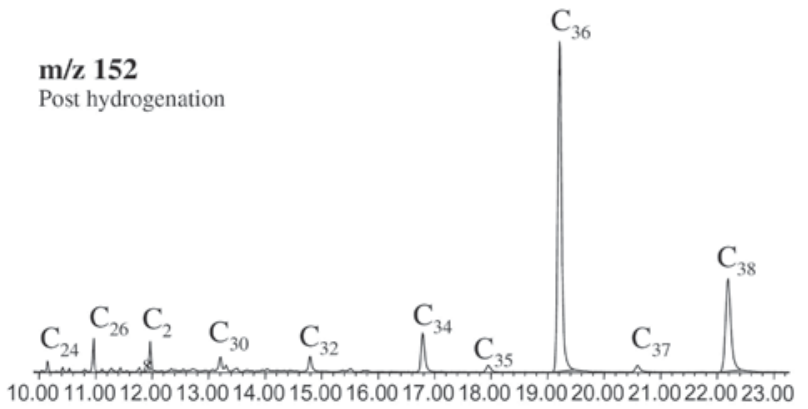

(b)

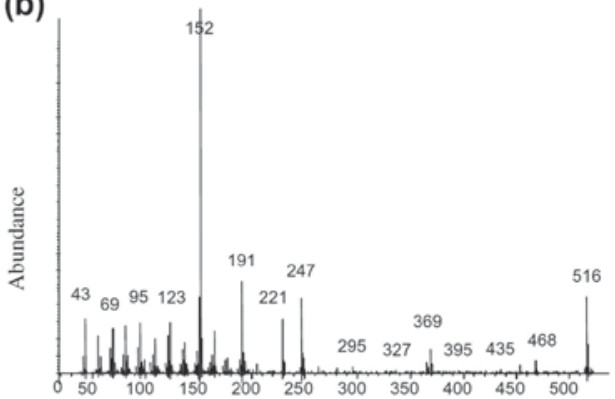

(d)

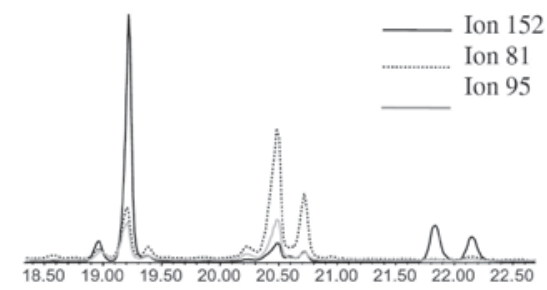

Figure 2. GC-MS data for a novel compound series found in a number of study sites: (a) Ion chromatogram of the compound series $\left(m / z\right.$ 152), (b) same as (a) but after hydrogenation, (c) mass spectrum of the $\mathrm{C}_{36: 0}$ homologue of the compound series, (d) Ion chromatogram showing elution of the unknown compound series $(\mathrm{m} / \mathrm{z} 152)$ in relation to alkenones (characterized by ions 81 and 95) on a DB-1 GC column.

suggesting the presence of two carbon rings in these compounds. Full structure elucidation of this compound series is beyond the scope of this paper. The discovery of this compound shows the importance of running all alkenone samples on the GC-MS to ensure the proper identification and quantification.

\section{Results}

\subsection{LCA occurrence and chain length distribution}

Of the 55 lake surface sediments examined in this study, $13(\sim 25 \%)$ contain detectable concentrations of LCAs (Table 2). LCA concentrations from 11 of the sites show wellresolved alkenone peaks in the GC-FID traces and are sufficiently high for accurate quantification. GC-MS analyses reveal that the $\mathrm{C}_{37: 4}, \mathrm{C}_{37: 3}, \mathrm{C}_{37: 2}$ and $\mathrm{C}_{38: 3}$ alkenones are present at Skoal Lake and $\mathrm{C}_{37: 3}$ and $\mathrm{C}_{37: 2}$ are present at Coldwater Lake. However, alkenone concentrations are very low, and peaks are poorly resolved in these two lakes. LCAs of chain lengths 37, 38, 39 and di-, tri-, and tetra-unsaturation were accurately quantified from the other 11 sites and are displayed as histograms in Figure 3a-k. The alkenones from 8 sites (Figure $3 \mathrm{~d}-\mathrm{k}$ ) show a complete lack of $\mathrm{C}_{37: 4}$ alkenone and contain $\mathrm{C}_{37: 3}$ as the dominant LCA.

\subsection{Enviromental data}

In our data set, major cation chemistry is dominated by sodium for seven of the nine lakes that contain alkenones and measured water chemistry (we lack cation data from Freshwater and Meng Lakes). The remaining two lakes
(Wickson and Coldwater) are respectively potassium or magnesium dominant, with sodium as the next major cation. LCAs were found only in sites with a $\mathrm{pH}$ range of 8.49.4. Lakes with $\mathrm{pH}>9.4$ did not contain alkenones. Sites with the $\mathrm{C}_{37: 4}$ alkenone all have $\mathrm{pH}$ below 9.0.

\subsection{LCA concentration}

$\mathrm{C}_{37}$ alkenone concentrations range from 1.17 to $670 \mu \mathrm{g}$ $\mathrm{C}_{37} \mathrm{~g}^{-1}$ of dry sediment (Table 2). The highest concentrations of alkenones occur in lakes in the northeastern section of our sampling area (e.g. Lake George, ND, Moon Lake, ND, and Medicine Lake, SD).

\subsection{Seasonal production of LCAs}

Seasonal sampling of water-column filtrates from Lake George from the timing of ice-off through the early fall in 2008 (May 16 through September 3) show that alkenones are produced in the water column in early spring, shortly after ice out. Over these 16 weeks, alkenones were present in the water column for the first 66 days (May 16 through July 21). At $5 \mathrm{~m}$ depth, alkenone concentration in lake water decreased logarithmically over the sampling season, while stratification index increased exponentially (Figure $4 \mathrm{a}$ and $\mathrm{b}$ ). All filters contain $\mathrm{C}_{37: 4^{\prime}}, \mathrm{C}_{37: 3^{\prime}}, \mathrm{C}_{37: 2^{\prime}}, \mathrm{C}_{38: 4 \mathrm{et}}$ $\mathrm{C}_{38: 3 e t, \mathrm{me}^{\prime}} \mathrm{C}_{38: 2 \mathrm{zet}, \mathrm{me}^{\prime}} \mathrm{C}_{39: 4^{\prime}}$ and $\mathrm{C}_{39: 3}$ LCAs. These LCAss are resolved and quantifiable in samples from May through July 9. After July 9, the concentrations fall below $4 \mu \mathrm{g} / \mathrm{L}$ water, and the $\mathrm{C}_{37}$ LCAs are not resolvable. Water samples collected through the ice in February 2009 from 0, 5, 10, and $13 \mathrm{~m}$ (max water depth at site $13.5 \mathrm{~m}$ ) were sampled for LCAs, but none were detected. 

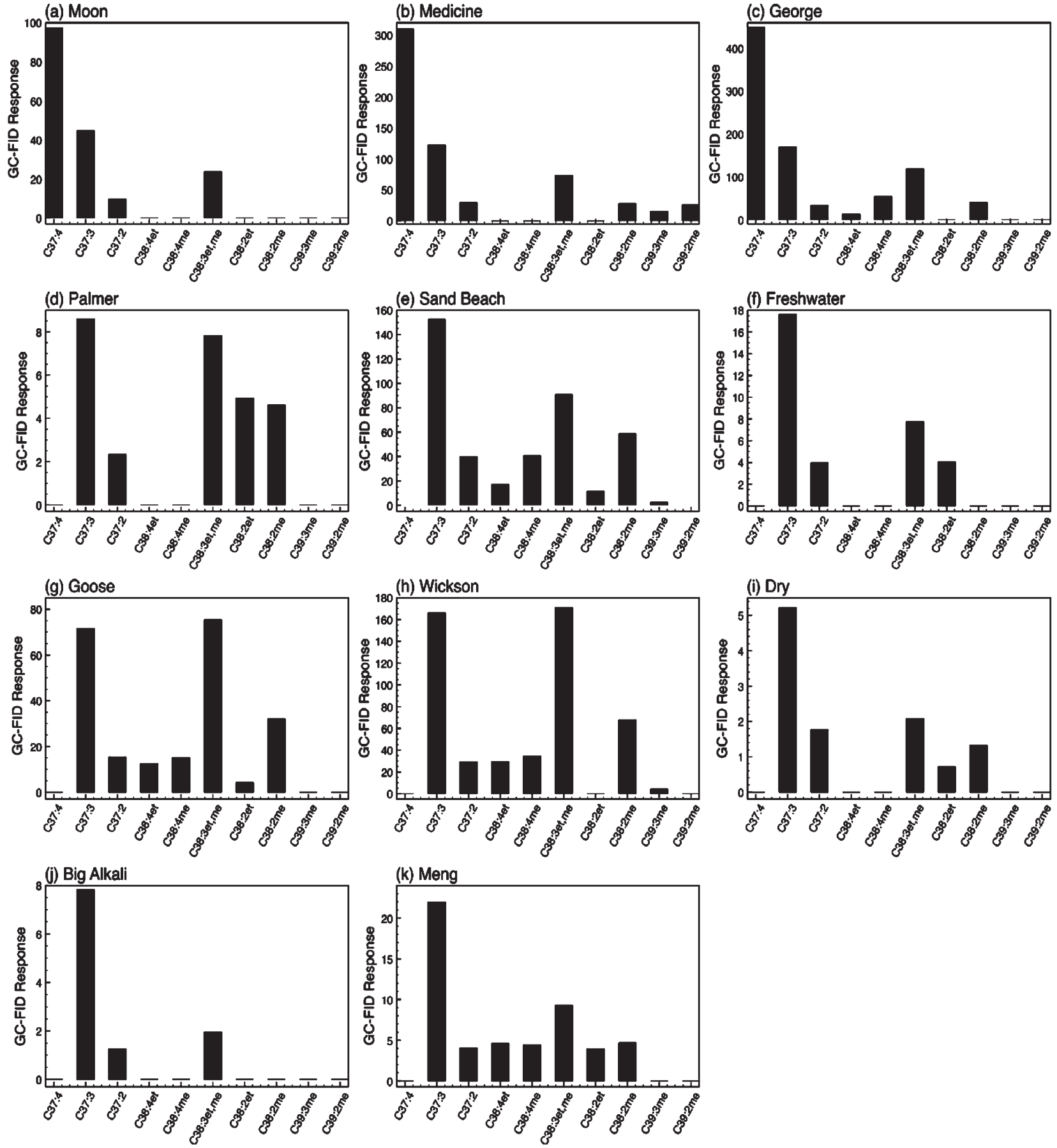

Figure 3. Histograms showing the relative abundance of long chain methyl and ethyl ketones for lake sites with quantifiable alkenone peaks. Lakes (a)-(c) are in the NGP and contain the $\mathrm{C}_{37: 4}$ alkenone, which is absent from the LCA profiles from the NE lakes shown in (d)-(k). (NGP, Northern Great Plains; MAAT, mean annual air temperature) (Note: Skoal Lake which contains $\mathrm{C}_{37: 4}$ and Coldwater Lake are not shown due to poorly resolved peaks.)

\section{Discussion}

\subsection{Environmental influences on LCA occurrence, concen- tration and chain length distribution}

\subsubsection{Groundwater controls on LCA distribution}

A first order control on the composition of LCAs in the NGP versus those in the NE Sand Hills appears to be the geochemistry of the groundwater sources feeding the lakes. Eastern SD and ND are underlain by the Upper Cretaceous aquifer that has low $(3000 \mathrm{mg} / \mathrm{L})$ to moderate total dissolved solids (up to 10,000 $\mathrm{mg} / \mathrm{L}$ ) (Whitehead, 1996). The shale unit confining this aquifer, the Pierre Shale, contributes to its dissolved mineral content, including abundant sulfate due to the oxidation of pyrite. This aquifer is a major water source for the lakes with the $\mathrm{C}_{37: 4}$ alkenones. In contrast, the NE Sand Hill lakes are within the High Plains aquifer, which is composed of Holocene eolian sands over- 
(a)
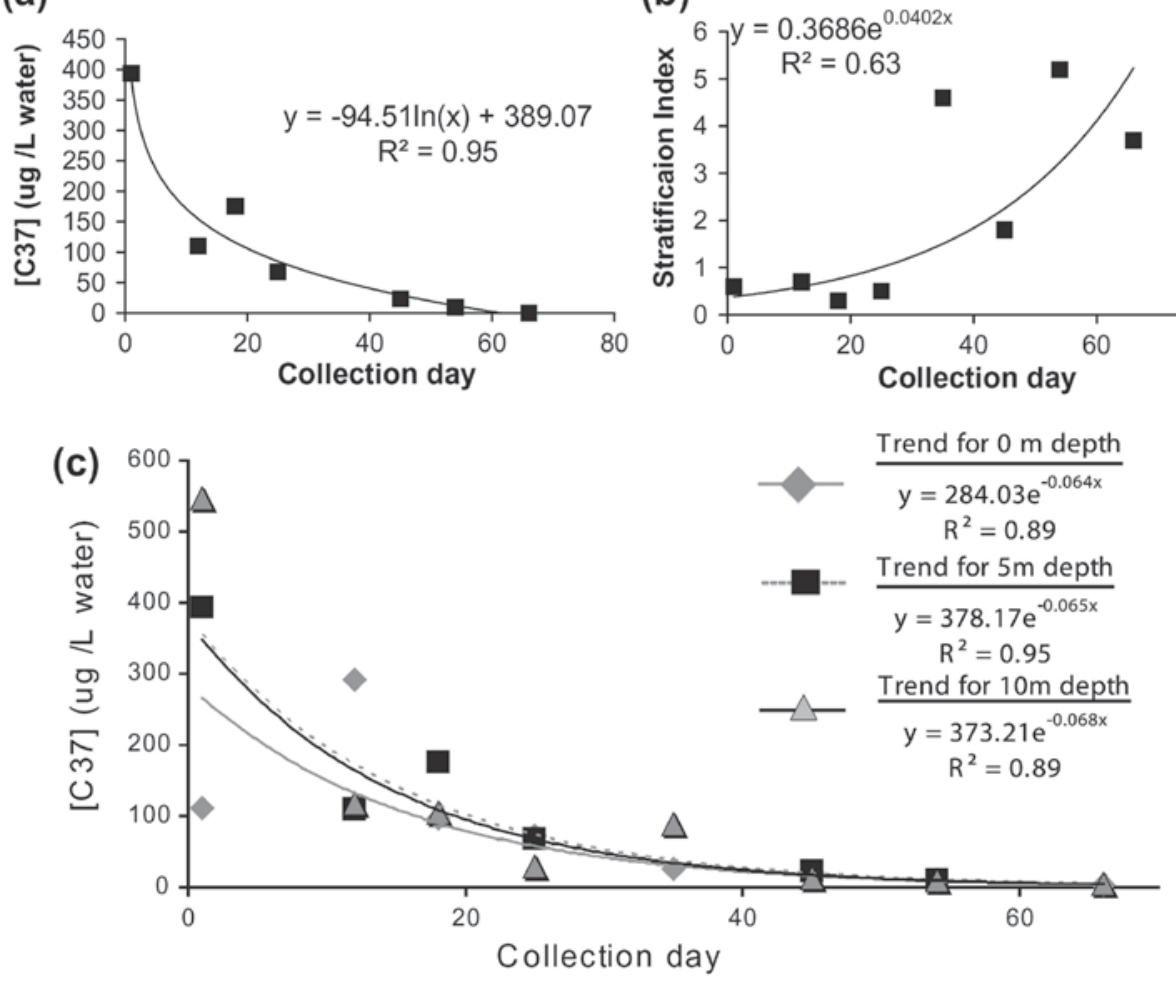

(b)

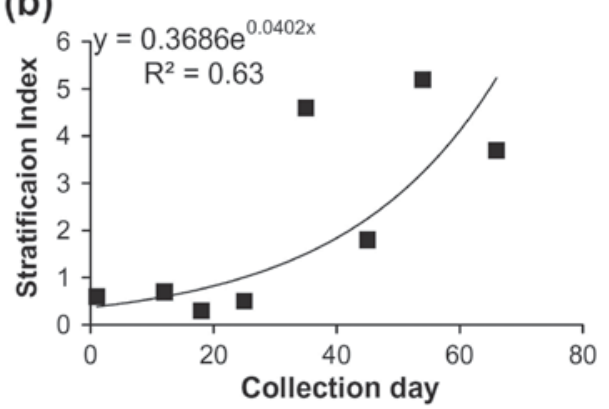

Figure 4. (a) Alkenone concentration data from water column sampling at $5 \mathrm{~m}$ depth from Lake George, ND. Day $1=$ May 16, 2008. (b) The stratification index (surface water temperature subtract the temperature at $10 \mathrm{~m}$ water depth) for Lake George, ND. (c) Alkenone concentration data from water column sampling at $0 \mathrm{~m}$ (diamonds), $5 \mathrm{~m}$ (squares) and $10 \mathrm{~m}$ (triangles) from Lake George, ND with exponential trend ( $0 \mathrm{~m}$ : gray solid line, $5 \mathrm{~m}$ : gray hatched line, $10 \mathrm{~m}$ : solid black line).

lying Pleistocene and late-Tertiary alluvial deposits and is mostly bicarbonate dominated (Bleed, 1998), as are the Sand Hill lakes that are fed by this aquifer.

\subsubsection{Carbonate and sulfate content on LCA distribution}

Six of the eight LCA-containing lakes in the NE Sandhills are carbonate-dominated, whereas, one (Freshwater Lake) is sulfate-dominated. Anion chemistry is not available for Meng Lake. All five LCA-containing lakes in the NGPs are sulfate-dominated, and four of the five lakes contain $\mathrm{C}_{37.4}$ (Table 1). The anion chemistry supports the geographic distribution of LCAs with one exception in the NE Sandhills. While the absolute concentration of sulfate and carbonate are variable in these sites (Table 2), the sulfate:carbonate ratio (SCR) is significantly different $(p<0.05)$ for the alkenone-containing NE Sandhill sites $(\mathrm{SCR}=0.01-2.59)$ that lack $\mathrm{C}_{37: 4}$ versus the alkenone-containing NGP sites $(\mathrm{SCR}=15.17-117.06)$ that contains abundant $\mathrm{C}_{37: 4}$ with the exception of Coldwater Lake. This suggests that the SCR is an important factor in determining the presence of $\mathrm{C}_{37: 4^{\prime}}$ which may be due to the presence of different haptophyte species, or the geochemistry may control $\mathrm{C}_{37: 4}$ production. If this separation is due to different taxa, then SCR may influence the competition between different haptophyte species. We speculate that lacustrine haptophytes may use similar adaptive advantages as marine haptophytes such as the adaptive advantage to use of sulfur under low-nitrogen conditions. Whereas most marine algae use GBT (glycine betaine - $\left.\left(\mathrm{CH}_{3}\right)_{3} \mathrm{~N}^{+} \mathrm{CH}_{2} \mathrm{COO}^{-}\right)$as an osmoregulator, some hap- tophytes can use DMSP ( $\beta$-dimethylsulphoniopropionate - $\left.\left(\mathrm{CH}_{2}\right)_{2} \mathrm{~S}^{+}\left(\mathrm{CH}_{2}\right)_{2} \mathrm{COO}^{-}\right)$, substituting sulfur for nitrogen under low nitrogen conditions (Andreae, 1986). Likewise, low nitrogen availability (shown in Salm et al. (2009)) and high sulfate concentrations (Table 2) in the NGP sites may make them more suitable for haptophytes that use DMSP. Alternatively, high sulfate may influence species composition by favoring haptophyte species that can use ammonium rather than nitrate, similar to a phenomenon that has been observed in culture experiments with saline-lake diatoms (Saros and Fritz, 2002).

In our data set, major cation chemistry is dominated by sodium for seven of the nine lakes that contain alkenones. The cation distribution is independent from geographic distribution, but suggests that elevated sodium may be a critical for alkenone production, although enhanced potassium concentration does not appear to interfere with LCA producing haptophytes.

Brush Lake, MT is an interesting site in the most northward and westward extent of our study region. Brush Lake is within the Williston Basin and is fed by a lower Tertiary freshwater aquifer. Although Zink et al. (2001) found alkenones in a Younger Dryas section of the Brush Lake sediment core and low concentrations in modern sediments (ca. 2001), the lake surface sediments collected in 2007 in this study do not contain alkenones. The late-Glacial and early Holocene sediments at Brush Lake, MT contain LCAs with $\mathrm{C}_{37: 4}$ dominance, which suggest that the source water for the lake had different relative contributions from groundwater 


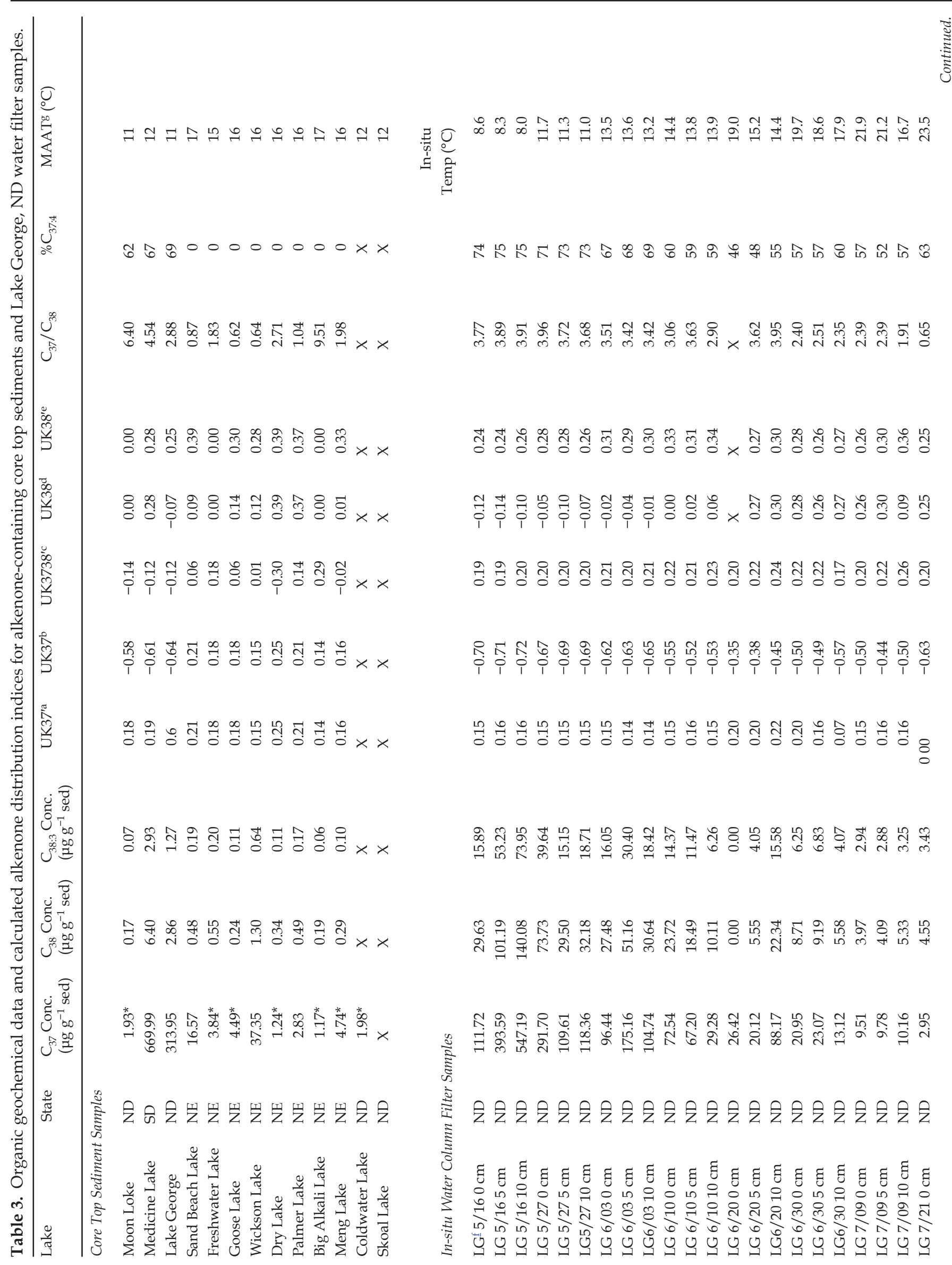


sources than today or that Cretaceous shales from glacial deposits added sulfate to the lake. Donovan (1994) shows that Brush Lake today receives groundwater from two sources, the eastern Grenora Channel and the western Clear Lake aquifer, which have very different $\mathrm{SO}_{4}$ concentrations; Grenora Channel $\left(\mathrm{SO}_{4}=\sim 1140 \mathrm{mg} / \mathrm{L}\right)$ and Clear Lake aquifer $\left(\mathrm{SO}_{4}<200 \mathrm{mg} / \mathrm{L}\right)$. In addition, the early Holocene hydrology in this region was much different from today due to the retreat of the Laurentide Ice Sheet and groundwater in shallow glacial deposits which had high concentrations of $\mathrm{SO}_{4}$ from gypsum dissolution (Hendry et al., 1986). We suggest that either scenario may have created more favorable geochemical conditions for alkenone-producing haptophytes in the early Holocene. In terms of the modern lake, Brush Lake is fresher today than two decades ago (conductivity decreased from 6450 to $1330 \mu \mathrm{S} / \mathrm{cm}$ between 1991 to 2004) (Fritz, unpublished data) and during the same period it switched from sulfate-dominated to a carbonate-dominated composition. Today, Brush Lake has the lowest SCR ratio of the NGP alkenone-containing sites (Table 2). Any of the seasonal changes in Brush Lake, including the freshening of the lake and associated changes in dominant ions, stratification, or nutrient regime may have produced an unsuitable habitat for the alkenone-producing algae that once inhabited in the lake.

\subsection{3. $L C A$ relationship to $p H$}

All alkenone-containing lakes in the study region are alkaline (Table 1), with $\mathrm{pH}$ ranging from 8.0 to 10.3. However, alkenones were found only in sites with a $\mathrm{pH}$ range between 8.4 and 9.4. Sites with the $\mathrm{C}_{37: 4}$ alkenone all have $\mathrm{pH}$ below 9.0. We also report that surface sediments collected from Mono Lake, CA, which has a $\mathrm{pH}>10$, has no alkenones despite having similar sodium $(60 \mathrm{mM})$ and sulfate levels $(120 \mathrm{mM})$ to our LCA-containing lakes. The effect of $\mathrm{pH}$ on haptophytes, if any, remains unknown.

\subsubsection{LCA occurrence and salinity}

Sites in which alkenones were detected cover a range of salinity (0.1-49.5 $\mathrm{g} \mathrm{L}^{-1}$ ) (Table 1$)$, all but one site with alkenones in the sediments have salinity $>1 \mathrm{~g} \mathrm{~L}^{-1}$. Thus, we suggest that elevated salinity is an important control on alkenone production. This is consistent with unpublished data from 33 fresh lakes in the eastern US (lakes in Huang et al., 2002) and 32 freshwater lakes from the southwestern US (lakes in Hou et al. (2008)) that show no detectable alkenones in modern sediments.

\subsubsection{Alkenone concentration}

Lake George, ND and Medicine Lake, SD have alkenone concentrations that are an order of magnitude higher than any of the other lakes (Table 3). The characteristics that differentiate Lake George and Medicine Lake from other regional lakes with lower alkenone concentrations are their greater depths, seasonal stratification, and high sulfate concentration. These two lakes, as well as nearby Moon Lake and Skoal Lake, are the only lakes that contain the $\mathrm{C}_{37: 4}$ alkenone, suggesting the presence of a different haptophyte species. One explanation for the higher alkenone concentrations 
in the two lakes that stratify is the presence of a physical refuge for haptophyte cells during times of the year when conditions are unsuitable for population growth. Similarly stratification and anoxic bottom waters may help preserve alkenones. In shallower lakes, physical mixing and biological interactions may reduce the number of viable cells that over-winter and germinate to produce the spring bloom and may cause degradation to sedimentary alkenones. Nutrient availability and high sulfate concentration also may play a role in the high alkenone concentrations in Lake George and Medicine Lake. During spring, overall primary production in the NGP sites commonly is both nitrogen and phosphorus limited, and $\mathrm{NO}_{3}$ concentrations are relatively low, even in the absence of lake water stratification (Salm et al., 2009). The occurrence of haptophytes in spring suggests that the alkenone producers may be adapted to low nutrient conditions (i.e. $\mathrm{S}$ for $\mathrm{N}$ replacement in osmoregulatory compounds and ammonium - nitrate substitution). Another adaptation to low nutrient conditions may be the reduction of phosphorus demand during times of low availability by substituting non-phosphorus lipids for phospholipids, as has been observed recently in marine phytoplankton (Van Mooy et al., 2009).

Another feature that separates the sites with the highest concentrations of LCAs, is their location in the northeastern section of our sampling area. This region is coincidentally the coldest part of our study region. The negative relationship between temperature and alkenone abundance has been found in both marine (Sikes et al., 1997; Volkman et al., 1998) and lacustrine (Cranwell, 1985; Zink et al., 2001) environments. For example, D'Andrea and Huang (2005) reported the highest alkenone concentrations in sediments in a set of Greenland lakes, with MAAT of $-31^{\circ} \mathrm{C}$.

\subsection{LCAs in core top sediments as a salinity and tempera- ture proxy}

\subsection{1. $C_{37: 4}$ proportion as a proxy for salinity}

The most distinctive feature of the $\mathrm{C}_{37}$ alkenone distribution among the study lakes is the presence or absence of the tetra-unsaturated ketone (Figure 3). All previously published data have shown that lacustrine alkenones contain $\mathrm{C}_{37: 4}$ and several studies suggest that the relative abundance of $\mathrm{C}_{37: 4}$ among $\mathrm{C}_{37}$ alkenones may be a function of salinity, with higher percentage of $\mathrm{C}_{37: 4}$ in lower salinity lakes (Chu et al., 2005; Liu et al., 2006). The four North American lakes that contain $\mathrm{C}_{37: 4}$ all have salinity higher than $2.74 \mathrm{~g} \mathrm{~L}^{-1}$, but the nine lakes that lack $\mathrm{C}_{37: 4}$ have a wide range of salinities (0.1-49.5 $\mathrm{g} \mathrm{L}^{-1}$ ) (Table 1). Our data suggest that there is no clear relationship between salinity and $C_{37: 4}$ presence or absence. Thiel et al. (1997) suggest that the presence of $\mathrm{C}_{37: 4}$ could be used as a facies marker for lacustrine or select marine settings, however, here we show for the first time that not all lacustrine settings contain the $\mathrm{C}_{37: 4}$ alkenone.

\subsubsection{Unsaturation indices and haptophyte taxonomy in core}

top sediments

$U_{37}^{K}, U_{37}^{K^{\prime}}, U_{3738}^{K^{\prime}}, U_{38^{\prime}}^{K}$ and $U_{38}^{K^{\prime}}$ indices (defined in Table 2) describe the degree of LCA unsaturation and were calculated for LCAs in the surface sediments of the NGP and NE Sand Hill lakes (Table 2). The $U_{37}^{K}$ index calibration to temperature has traditionally been used in alkenone lake studies (Zink et al., 2001; D' Andrea and Huang, 2005); however, in a recent study, Pearson et al. (2008) use the $U_{38}^{K}$ index for lakes with low $C_{37}$ concentrations. Pearson et al. (2008) suggest that predominance of $C_{38}$ LCAs may be related to alkalinity or salinity. There is no correlation between $U_{38}^{K}$ and salinity at our sites. Similarly, Pearson et al. (2008) hypothesize that the dominance of C38:3 could be an indicator of alkaline, evaporitic or saline settings; however, at our sites regressions were run for all LCA chain lengths versus all environmental parameters for core top LCAs. The C38:3 alkenone shows no significant relationship to temperature $\left(r^{2}=0.35\right)$, salinity $\left(r^{2}=0.0003\right), \mathrm{pH}\left(r^{2}=0.45\right)$, or alkalinity $\left(r^{2}=0.075\right)$.

\subsection{3. $C_{37}: C_{38}$ ratio and haptophyte taxonmomy}

We do find that the $C_{37}: C_{38}$ ratio is highest $(4.6 \pm 1.8)$ in the lakes with $\mathrm{C}_{37: 4}$ and $\mathrm{C}_{38}$ LCAs are dominant in those that do not contain $\mathrm{C}_{37: 4}\left(\mathrm{C}_{37}: \mathrm{C}_{38}=2.4 \pm 2.9\right)$ (Figure 5). In these two groups of lakes, NE Sandhills versus NGP, the $\mathrm{C}_{37}: \mathrm{C}_{38}$ ratio is significantly different $(p<0.01)$. This ratio has been used in other studies to infer haptophyte taxonomy (Pearson et al., 2008). Based on previously determined $\mathrm{C}_{37}: \mathrm{C}_{38}$ ratios, our NGP sites group closely to Isochrysis galbana and Chrysotila lamellosa (Marlowe et al., 1984; Rontani et al., 2004), while our NE Sandhill sites are more similar to Emiliana huxleyi (Marlowe et al., 1984) or Chinese Lakes (Sun et al., 2007; Chu et al., 2005). This taxonomic separation is also supported by the LCA distribution, because published lacustrine alkenone distributions are characterized by high abundances of the $\mathrm{C}_{37: 4}$, such as those in English (Cranwell, 1985), Asian (Li et al., 1996; Chu et al., 2005), Antarctic (Volkman et al., 1988) and German (Zink et al., 2001) lake sediments, as well as Pliocene, Oligocene, and Eocene samples (Marlowe et al., 1984; Marlowe et al., 1990). The alkenone distributions for lakes that lack $\mathrm{C}_{37: 4}$ are most similar to those reported from the North Atlantic (RosellMelé et al., 1994; Brassell et al., 1986), North Sea (Volkman et al., 1980), the Mediterranean (Cacho et al., 1999), and other marine sites. Interestingly, Pearson et al. (2008) report the dominance of $\mathrm{C}_{37: 3}$ over $\mathrm{C}_{37: 4}$ in Spanish lakes.

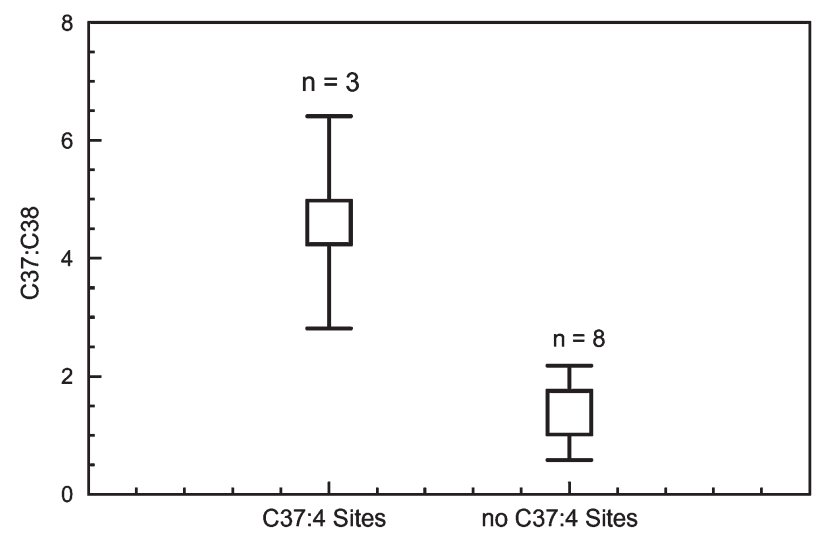

Figure 5. The $\mathrm{C}_{37}: \mathrm{C}_{38}$ ratio distribution for lakes that contain the $\mathrm{C}_{37: 4}$ LCA versus lakes that do not contain $\mathrm{C}_{37: 4}$. 


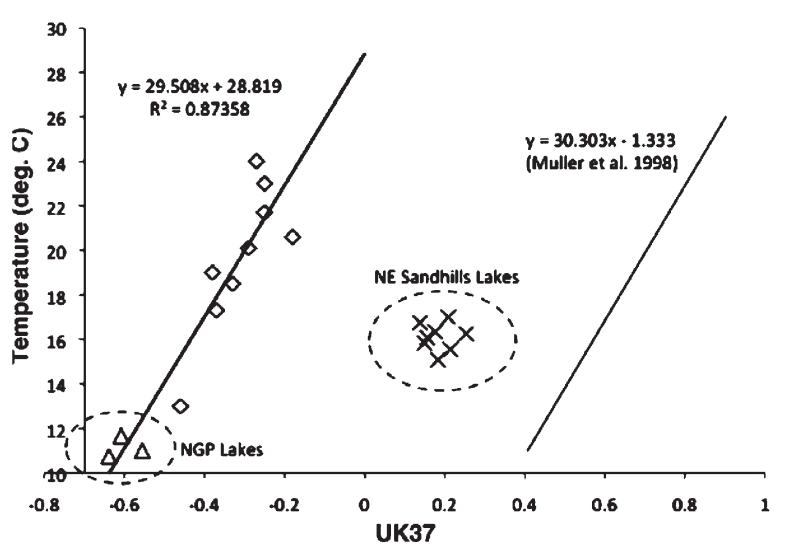

Figure 6. The previously published Zink et al. (2001) lacustrine LCA $U_{37}^{K}$ calibration (diamonds) with the NGP core top $U_{37}^{K}$ (triangles), the NE Sand Hill sites $U_{37}^{K}(X)$ and the accepted marine linear calibration from Müller et al. (1998). (NGP, Northern Great Plains; MAAT, mean annual air temperature).

\subsubsection{Unsaturation indices and temperature}

The $U_{37}^{K}, U^{K^{\prime}}{ }_{37}, U_{3738^{\prime}}^{K} U_{38^{\prime}}^{K}$ and $U_{38}^{K^{\prime}}$ indices were all regressed against a variety of environmental temperatures from the lake sites, including: July lake temperature at $0.5 \mathrm{~m}$ depth, MAAT, mean summer air temperature (AT), mean fall AT, and mean winter AT. Regressions against these variables showed no significant correlation. Instead, the two geographic groups consistently clustered showing the difference between the north and south regions, where presumed taxonomic differences in haptophytes preclude the use of these indices for calibration to climate parameters from our core top sediments. Whether or not such a taxonomic difference could itself be related to environmental temperature is not yet known. Because no correlation was found between $U^{K^{\prime}}{ }_{37}, U_{3738^{\prime}} U^{K}{ }_{38}$, or $U^{K^{\prime}}{ }_{38}$ and temperature, temperature may not be the primary environmental factor affecting these indices. Instead these indices may respond to light, nutrients, or other environmental factors independent from $\mathrm{C}_{37: 4}$.

\subsubsection{Potential degradation of LCAs}

While we acknowledge studies that suggest there may be differential degradation of LCAs dependent on the degree of saturation (Gong and Hollander, 1999; Rontani et al., 2005), there are several lines of evidence to suggest that differences between NGP and NE Sandhill sites are taxonomic differences (i.e. the geographic separation, $C_{37}: C_{38}$ ratio, SCR). Degradation is an important question to test in order to the use LCAs as a temperature proxy and should be considered when choosing a site for reconstruction. For example, Gong and Hollander (1999) show that less saturated chains degrade preferentially over more saturated chains in oxic sediments, Teece et al. (1998) show that no chain length alteration occurs during anaerobic degradation. As such, a site should be chosen that is thought to have remained anoxic for the length of the reconstruction. As Teece et al. (1998) report and is seen in high-sulfate lakes in Greenland (D'Andrea and Huang, 2005), alkenones tend to preserve better under sulfate-reducing conditions. These are important considerations for proxy reconstruction and guide our future plans for a reconstruction from Lake George, ND (60 m maximum depth; $12,210 \mathrm{mg} / \mathrm{L} \mathrm{SO}_{4}$ ).

\subsubsection{Comparison of Core Top LCAs to a known calibration}

The only other lacustrine alkenone calibration to $U_{37}^{K}$ (Zink et al., 2001) found a significant relationship between $U_{37}^{K}$ and summer surface water temperature in German lake sites $\left(r^{2}=0.67\right)$. The lack of correlation to July surface water temperature in our sites could be a function of several factors. For example, (1) alkenone production may not occur during mid-summer in our region-based on in-situ water column filtration in the NGP lakes, alkenones were not present in July of 2007; (2) even if present, the alkenone producers may not inhabit the uppermost waters (0.5 meters water depth) - Zink et al. (2001) suggested that haptophyte habitat may be deeper in the water column; (3) summer surface water temperature is a point sample that can change significantly over short time periods, whereas the sediment record presumably captures a more integrated period of time.

If we plot the $U_{37}^{K}$ values of the three NGP lakes that contain $\mathrm{C}_{37: 4}$ versus MAAT, the relationship fits well along the calibration previously determined for German lakes (Zink et al., 2001) (Figure 6). While the slopes of the surface water temperature- $U_{37}^{K}$ relationship are similar in German lakes and the oceans (Müller et al., 1998), there is a large difference between the values of $U_{37}^{K}$ in these two measurements at a given temperature. Moreover, the NE Sand Hills lakes occupy a third space (Figure 6) that does not agree with either the lacustrine or marine array. This is further evidence that the NE Sand Hills sites may contain a new and unique haptophyte species. Sedimentary rDNA samples have been collected and are being analyzed at the Marine Biology Lab, Woods Hole for more conclusive taxonomic distinctions. It is not clear why our $\mathrm{C}_{37: 4}$ plotted versus MAAT falls along the calibration for German Lakes of surface water temperature- $U_{37}^{K}$. Here we suggest that lack of information on lacustrine haptophyte habitat limits our ability to precisely define what specific environmental temperature these organisms record in different lakes.

\subsection{Single site LCA proxy calibration}

\subsubsection{Seasonal water sampling and haptophyte ecology}

Much remains unknown about production of alkenones in lakes. Here we focus field studies on the lake in our study region with the highest concentrations of sedimentary alkenones to understand when and in what part of the water column the alkenones are produced. Seasonal sampling of water-column filtrates from Lake George, ND beginning at ice-off through the early fall in 2008 (May 16 through September 3) indicates that the haptophyte bloom at the surface begins in early spring, shortly after ice out. Over these 16 weeks, alkenones were present in the water column for the first 66 days (May 16 through July 21). LCAs are in the highest concentrations initially at $10 \mathrm{~m}$, then $5 \mathrm{~m}$, then $0 \mathrm{~m}$ suggesting that they ascend through the water column over the course of $\sim 20$ days (Figure $4 \mathrm{a}$ ). Alkenone concentrations in lake water at $5 \mathrm{~m}$ depth decreased logarithmically, while 
stratification index increased exponentially (Figure $4 \mathrm{~b}$ and c). LCA concentrations decreased as stratification index intensified, and as the epilimnion wared. This observed sequence suggests that the LCA producers may have a winter resting stage, similar to haptophyte taxa Prymnesium (Billard, 1994), at depth during ice-cover and subsequently move toward the surface when triggered by a critical environmental parameter. Water column samples collected at multiple depths in February 2009 contain no LCAs and suggest the organisms are not present in the water column. Culture experiments have previously suggested that the movement of Chrysophytes toward the surface is influenced by light (Holen, 1999). Similarly, the movement of the alkenone-producers to the surface in spring may be triggered by solar radiation, while cool water and a relative increase in nutrients associated with water-column mixing promote the bloom. Culture samples from Lake George collected in the spring of 2009, contain mobile algae with 2 unequal flagella that we suspect are haptophytes. Cultures also contain colonizing green algae and have been sub-sampled to isolate a monoculture. Unfortunately, so far we have failed to find alkenones in laboratory cultures incubated from Lake George water.

\subsubsection{Unsaturation indices from in-situ water column samples} from Lake George, ND: a new approach in calibrating alkenones to temperature in lakes

Due to the presumed difference in algal species between the NGP sites and the NE Sand Hill sites, development of a core-top $U_{37^{-}}^{\mathrm{K}}$ temperature calibration in interior US lakes is not possible. Culture samples were collected in June of 2009, after the 2008 monitoring season and enough data was collected to predict the time of their presence in the water column. A culture calibration is forthcoming. Here we use a novel approach to such a calibration for sites containing $\mathrm{C}_{37: 4}$ LCA using water column filters collected at 0 , 5, and $10 \mathrm{~m}$ depth from May 16, 2008 through July 21, 2008 and additional sampling in June, 2009 from Lake George, ND. During this time, water temperatures range from
2 to $22{ }^{\circ} \mathrm{C}$ (Table 2). The $U_{37}^{K}$ index has a significant relationship to lake water temperature $\left(r^{2}=0.75\right)$ (Figure $\left.7 \mathrm{a}\right)$; whereas the $U^{K^{\prime}}$ shows no correlation $\left(r^{2}=0.14\right)$ to lake water temperature. This suggests that $\mathrm{C}_{37: 4}$ responds much more strongly than $\mathrm{C}_{37: 3}$ or $\mathrm{C}_{37: 2}$, but the proportion of $\mathrm{C}_{37: 3}$ to $\mathrm{C}_{37: 2}$ still has a small response, otherwise the index would not work. The $U^{K^{\prime}}{ }_{37}$ shows about one quarter of the variance $(0.004)$ than the $U_{37}^{K}$ index $(0.016)$ across the filter data, and $C_{37.4}$ ranges between $46 \%$ and $81 \%$ of the $C_{37}$ homologues. Not surprisingly, due to the predominance of $\mathrm{C}_{37: 4}$ alkenone, the proportion of $\mathrm{C}_{37: 4}$ is also linearly correlated to temperature $\left(r^{2}=0.73\right)$ (Figure $\left.7 b\right)$. Scatter about the linear calibration may be the result of alkenones produced close to the lake surface that subsequently rain down, or deeper alkenones brought up via wind mixing.

This Lake George in-situ $U_{37}^{K}$ calibration predicts consistently higher temperature values than the calibration of Zink et al. (2001), although the slopes are similar (Figure 7c). The main difference between these calibrations is that the Lake George calibration documents the LCA ratios from presumably live organisms and compares them directly with the temperature at which they are growing. This technique is similar to that of Goni et al (2004) where the $U_{37}^{K^{\prime}}$ of LCAs in sediment traps in the Cariaco Basin correlates to seasonal changes in SSTs. The Zink et al. (2001) calibration compares alkenones from core top sediments, which may combine multiple years and different growth depths into a single sample to a single summer surface lake-water temperature. By using in-situ measurements, we remove the complicating factors of taphonomy and alkenone transport to the sediments, growth depth, and seasonal bias from our calibration. We suggest that this new calibration is the best for the $\mathrm{C}_{37: 4}$-containing lakes in the NGPs.

\section{Conclusions}

The discovery of 13 new alkenone sites from the interior US provide new understanding regarding lacustrine
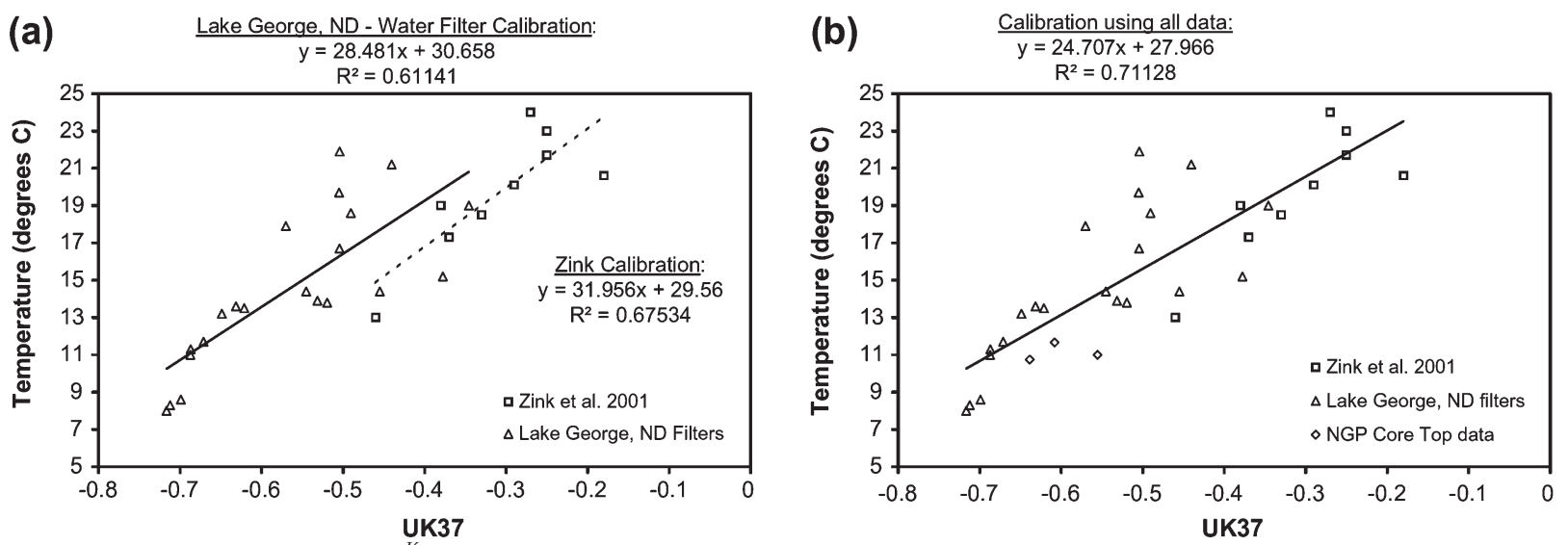

Figure 7. (a) The lacustrine LCA $U_{37}^{K}$ calibration from the 2008 Lake George, ND for water column filters with in-situ lake water temperature (linear regression $r^{2}=0.74, p<1.4 \times 10^{-8}$ ), (b) The proportion of $\mathrm{C}_{37: 4}$ from Lake George, ND water column filters plotted versus in-situ lake water temperature (linear regression $r^{2}=0.72, p<4.0 \times 10^{-8}$ ). (c) The lacustrine LCA $U_{37}^{K}$ calibration from the 2008 Lake George, ND for water column filters with in-situ lake water temperature versus the Zink et al. (2001) calibration of $U_{37}^{K}$ with summer surface water temperature. 
alkenone presence, abundance, and distribution. We show that: (1) The highest concentrations of alkenones are found in deep, cold lakes with high sodium and sulfate concentrations and a $\mathrm{pH}$ range 8.4-9.0; (2) A potentially new lacustrine haptophyte species, as suggested by a relatively low $\mathrm{C}_{37}: \mathrm{C}_{38}$ ratio and the absence of $\mathrm{C}_{37: 4} \mathrm{LCA}$ exists in the lakes of the interior US. The haptophyte taxa in NGP sites and NE sandhill sites are strongly separated according to the SCR of the lake water; (3) Alkenone-producers bloom in the early spring in Lake George, probably triggered by increased solar radiation. The bloom is promoted by cool water temperatures and increased nutrient concentrations due to lake overturning; (4) A new alkenone unsaturation to temperature calibration is derived from water column filtration from Lake George. It is the first time that such a approach is used to derived LCA temperature calibration; (5) We demonstrate that the $U_{37}^{K^{\prime}}$ in our study sited is not sensitive to temperature; and (6) Alkenone samples must be run on the GC-MS to ensure the correct identification of compounds due to an unknown compound series (key ion $m / z$ 152).

Our study provides an improved understanding on the environmental conditions promoting the occurrence of alkenones in lakes. The environmental parameters that apparently most strongly affect the LCA distribution are salinity, SCR and temperature. For the first time we show that the SCR of lake water strongly influences the presence of $\mathrm{C}_{37: 4}$. This ratio should be assessed for marine and lacustrine sites from which LCAs are reported. The presence of the $\mathrm{C}_{37: 4}$, is geographically restricted to sites in the northeastern portion of our study area. These sites generally have cooler temperatures and a dominance of sodium and sulfate ions. The addition of new sites, from a larger geographic and environmental range will help to further define the conditions in which LCAs are produced and will further aid in interpreting LCAs in the paleoclimate record.

\section{Acknowledgments}

This work was supported by grants from the National Science Foundation to Y. Huang (EAR06-02325), Sherilyn Fritz and Eric Grimm (EAR06-02154) and Paul Baker (EAR06-01779). We appreciate the constructive suggests of Klaus Zink and two anonymous reviewers, whose feedback greatly strengthened the manuscript. We would like to thank Marcelo Alexandre for assistance during laboratory analysis; John and Aris Holz for water chemistry analysis of the NE sites; Danuta Bennett, John Holz, and Tad Barrow for assistance in collection of NE Sand Hill samples; and M. Isler for access at Lake George. Many thanks to Rick Bohn for collecting water samples without which this work would not be possible.

\section{References}

Andreae, 1986 M. O. Andreae, Dimethylsulfoxide in marine and freshwaters, Limnol. Oceanogr. 25 (1986), pp. 357-364.

Bennett et al., 2007 D. M. Bennett, S. C. Fritz, J. C. Holz, and V. A. Zlotnik, Evaluating climatic and non-climatic in- fluences on ion chemistry in natural and man-made lakes of Nebraska, USA, Hydrobiologia 591 (2007), pp. 103-115.

Billard, 1994 G. Billard, Life cycles. In The Haptophyte Algae (eds. J. C. Green and B. S. C. Leadbeatter). The Systematics Association Special Volume 51 (1994), pp. 167-186.

Bleed, 1998 A. Bleed, Groundwater. In: A. S. Bleed and C. A. Flowerday, Editors, An Atlas of the Sand Hills (3rd ed. ), University of Nebraska, Lincoln (1998), pp. 17-28.

Brassell et al., $1986>$ S. C. Brassell, G. Eglinton, I. T. Marlowe, and M. Sarnthein, Molecular stratigraphy: a new tool for climatic assessment, Nature 320 (1986), pp. 129-133.

Cacho et al., 1999 I. Cacho, J. O. Grimalt, C. Pelejero, M. Canals, F. J. Sierro, J. A. Flores, and N. J. Shackleton, Dansgaard-Oeschger and Heinrich event imprints in Alboran Sea temperatures, Paleoceanography 14 (1999), pp. 698-705.

Chu et al., 2005 G. Chu, Q. Sun, S. Li, M. Zheng, X. Jia, C. Lu, J. Liu, and T. Liu, Long-chain alkenone distributions and temperature dependence in lacustrine surface sediments from China, Geochim. Cosmochim. Acta 69 (2005), pp. 4985-5003.

Coolen et al., 2004 M. H. Coolen, G. Muyzer, W. I. C. Rijpstra, S. Schouten, J. K. Volkman, and J. S. S. Damsté, Combined DNA and lipid analyses of sediments reveal changes in Holocene haptophyte and diatom populations in an Antarctic lake, Earth Planet. Sci. Lett. 223 (2004), pp. 225-239.

Cranwell, 1985 - P. A. Cranwell, Long-chain unsaturated ketones in recent lacustrine sediments, Geochim. Cosmochim. Acta 49 (1985), pp. 1545-1551.

D'Andrea and Huang, $2005-$ W. J. D'Andrea and Y. Huang, Long-chain alkenones in Greenland lake sediments: Low $\delta^{13} \mathrm{C}$ values and exceptional abundance, Org. Geochem. 36 (2005), pp. 1234-1241.

D'Andrea et al., 2006 W. J. D'Andrea, M. Lage, J. B. H. Martiny, A. D. Laatsch, L. A. Amaral-Zettler, M. L. Sogin, and Y. Huang, Alkenone producers inferred from wellpreserved 18S rDNA in Greenland lake sediments, J. Geophys. Res. 11 (2006), pp. 1-8.

Donovan, 1994 J. J. Donovan, On the measurement of reactive mass fluxes in evaporite groundwater-source lakes, Sedimentol. Geochem. Modern and Ancient Saline Lake, SEPM (1994), pp. 33-50 Special publication No. 50.

Gong and Hollander, 1999 C. Gong and D. J. Hollander, Evidence for differential degradation of alkenones under contrasting bottom water oxygen conditions: implication for paletemperature reconstruction, Geochim. Cosmochim. Acta 63 (1999), pp. 405-411.

Goni et al., 2004 M. A. Goni, M. P. Woodworth, H. L. Aceves, R. C. Thunell, E. Tappa, D. Black, F. MüllerKarger, Y. Astor, and R. Varela, Generation, transport, and preservation of the alkenone-based $\mathrm{U}_{37}{ }^{\mathrm{K}^{\prime}}$ sea surface temperature index in the water column and sediments of the Cariaco Basin (Venezuela), Global Biogeochem. Cycles 18 (2004), pp. 1-21.

Hendry et al., 1986 M. J. Hendry, J. A. Cherry, and J. H. Wallick, Origin and distribution of sulfate in a fractured till in southern Alberta, Canada, Water Resour. Res. 22 (1986), pp. 45-61.

Holen, $1999-$ D. A. Holen, Effects of prey abundance and light intensity on the mixotrophic chrysophyte Poterioochromonas malhamensis from a mesotrophic lake, Freshwater Biol. 42 (1999), pp. 445-455. 
Hou et al., 2008 J. Hou, W. D'Andrea, and Y. Huang, Can sedimentary leaf waxes record $\mathrm{D} / \mathrm{H}$ ratios of continental precipitation? Field, model, and experimental assessments, Geochim. Cosmochim. Acta 72 (2008), pp. 3503-3517.

Huang et al., 2002 Y. Huang, B. Shuman, Y. Wang, and T. Webb, Hydrogen isotope ratios of palmitic acid in lacustrine sediments record late Quaternary climate variations, Geology 30 (12) (2002), pp. 1103-1106.

Kim et al., 2008 J. H. Kim, S. Schouten, E. C. Hopmans, B. Donner, and J. S. Sinninghe Damsté, Global sediment core-top calibration of the $\mathrm{TEX}_{86}$ paleothermometer in the ocean, Geochim. Cosmochim. Acta 72 (2008), pp. 1154-1173.

Lawrence et al., $2005 \rightarrow$ K. T. Lawrence, Z. Liu, and T. D. Herbert, Evolution of the eastern tropical Pacific through PlioPleistocene glaciation, Science 312 (2005), pp. 79-83.

de Leeuw et al., $1980 \rightarrow$ J. W. de Leeuw, F. W. van der Meer, and W. I. C. Rijpstra, On the occurrence and structural identification of long chain unsaturated ketones and hydrocarbons in sediments. In: A. D. Douglas and J. R. Maxwell, Editors, Advances in Organic Geochemistry 1979, Pergamon (1980), pp. 2311-2317.

Li et al., 1996 J. G. Li, R. P. Philip, F. Pu, and J. Allen, Longchain alkenones in Qinghai lake sediments, Geochim. Cosmochim. Acta 60 (1996), pp. 235-241.

Liu et al., 2006 Z. Liu, A. C. G. Henderson, and Y. Huang, Alkenone-based reconstructions of late-Holocene surface temperature and salinity changes in Lake Qinghai, China, Geophys. Res. Lett. 33 (2006), pp. 1-4.

Marlowe et al., 1984 I. T. Marlowe, S. C. Brassell, G. Eglinton, and J. C. Green, Long chain unsaturated ketones and esters in living algae and marine sediments, Org. Geochem. 34 (1984), pp. 261-289.

Marlowe et al., 1990 I. T. Marlowe, S. C. Brassell, G. Eglinton, and J. C. Green, Long-chain alkenones and alkyl alkenoates and the fossil coccolith record of marine-sediments, Chem. Geol. 88 (1990), pp. 349-375.

Moreno et al., 2004 A. Moreno, I. Cacho, M. Canals, J. O. Grimalt, and A. Sanchez-Vidal, Millennial-scale variability in the productivity signal from the Alboran Sea record, Western Mediterranean Sea, Palaeogeogr. Palaeoclimatol. Palaeoecol. 211 (2004), pp. 205-219.

Müller et al., $1998>$ P. J. Müller, G. Kirst, G. Ruhland, I. von Storch, and Rosell-Melé, Calibration of the alkenone paleotmperature index U37K based on core-tops from the eastern South Atlantic and the global ocean $\left(60^{\circ} \mathrm{N}-60^{\circ} \mathrm{S}\right)$, Geochim. Cosmochim. Acta 62 (1998), pp. 1757-1772.

Pearson et al., 2008 E. J. Pearson, S. Juggins, and P. Farrimond, Distribution and significance of long-chain alkenones as salinity and temperature indicators in Spanish saline lake sediments, Geochim. Cosmochim. Acta 72 (2008), pp. 4035-4046.

Peterse et al., 2009 F. Peterse, J. H. Kim, S. Schouten, D. K. Kristenseen, N. Koç, and J. S. Sinninghe Damasté, Constraints on the application of the MBT/CBT palaeothermometer at high latitude environments (Svalbard, Norwary), Org. Geochem. 40 (6) (2009), pp. 692-699.

Porinchu and MacDonald, 2003 D. F. Porinchu and G. M. MacDonald, The use and application of freshwater midges (Chironomidae: Insecta: Diptera) in geographical research, Prog. Phys. Geogr. 27 (2003), pp. 378-417.

Powers et al., 2004 L. A. Powers, J. P. Werne, T. C. Johnson, E. C. Hopsman, J. S. Sinninghe Damasté, and S. Schouten,
Crenarchaeotal membrane lipids in lake sediments: A new paleotemperature proxy for continental paleoclimate reconstruction?, Geol. Soc. Am. 32 (7) (2004), pp. 613-616.

Prahl and Wakeham, 1987 F. G. Prahl and S. G. Wakeham, Calibration of unsaturation patterns in long-chain ketone compositions for palaeotemperature assessment, Nature 330 (1987), pp. 367-369.

Prahl et al., 1988 F. G. Prahl, L. A. Meuhlhausen, and D. L. Zahnle, Further evaluation of long-chain alkenones as indicators of palaeoceanographic conditions, Geochim. Cosmochim. Acta 52 (1988), pp. 2303-2310.

Prahl et al., 2005 F. G. Prahl, B. N. Popp, D. M. Karl, and M. A. Sparrow, Ecology and biogeochemistry of alkenone production at Station ALOHA, Deep Sea Res. I 52 (2005), pp. 699-719.

Rontani et al., 1997 J. F. Rontani, P. Cuny, V. Grossi, and B. Beker, Stability of long-chain alkenones in senescing cells of Emiliania huxleyi: effect of photochemical and aerobic microbial degradation of the alkenone unsaturation ratio $\mathrm{U}_{37}{ }^{\mathrm{K}}$, Org. Geochem. 26 (1997), pp. 503-509.

Rontani et al., 2004 J. F. Rontani, B. Beker, and J. K. Volkman, Long-chain alkenones and related compounds in the benthic haptophyte Chrysotila lamellosa Anand HAP 17, Phytochemistry 65 (2004), pp. 117-126.

Rontani et al., $2005-$ J. F. Rontani, P. Bonin, I. Jameson, and J. K. Volkman, Degradation of alkenones and related compounds during oxic and anoxic incubation of the marine haptophyte Emiliania huxleyi with bacterial consortia isolated from microbial mats from the Camargue, France, Org. Geochem. 36 (2005), pp. 603-618.

Rosell-Melé et al., 1994 A. Rosell-Melé, J. Carter, and G. Eglinton, Distributions of long-chain alkenones and alkyl alkenoates in marine surface sediments from the North East Atlantic, Org. Geochem. 22 (1994), pp. 501-509.

Rosell-Melé et al., 1995 A. Rosell-Melé, G. Eglinton, U. Pflaumann, and M. Sarnthein, Atlantic core-top calibration of the $\mathrm{U}_{37}{ }^{\mathrm{K}}$ index as a sea-surface palaeotemperature indicator, Geochim. Cosmochim. Acta 59 (1995), pp. 3099-3107.

Rueda et al., 2009 G. Rueda, A. Rosell-Melé, M. Escala, R. Gyllencreutz, and J. Backman, Comparison of instrumental and GDGT-based estimates of sea surface and air temperatures from the Skagerrak, Org. Geochem. 40 (2009), pp. 287-291.

Saros and Fritz, 2002 J. E. Saros and S. C. Fritz, Resource competition among saline-lake diatoms under varying $\mathrm{N} / \mathrm{P}$ ratio, salinity and anion composition, Freshwater Biol. 47 (2002), pp. 87-95.

Salm et al., $2009 \rightarrow$ C. R. Salm, J. E. Saros, S. C. Fritz, C. L. Osburn, and D. M. Reieneke, Phytoplankton productivity across prairie saline lakes of the Great Plains (USA): A step toward deciphering patterns through lake classification models, Can. J. Fisheries Aquatic Sci. 66 (9) (2009), pp. 1435-1448.

Schouten et al., $2002>$ S. Schouten, E. C. Hopmans, E. Schefuß, and J. S. Sinninghe Damsté, Distributional variations in marine crenarchaeotal membrane lipids: a new tool for reconstructing ancient sea water temperatures?, Earth Planet. Sci. Lett. 204 (2002), pp. 265-274.

Sikes and Volkman, 1993 E. L. Sikes and J. K. Volkman, Calibration of alkenone unsaturation ratios (UK) for paleotemperature estimation in cold polar waters, Geochim. Cosmochim. Acta 57 (1993), pp. 1883-1889. 
Sikes et al., 1997 E. L. Sikes, J. K. Volkman, L. G. Robertson, and J. -J. Pichon, Alkenones and alkenes in surface water and sediments of the Southern Ocean: implications for paleotemperature estimation in polar regions, Geochim. Cosmochim. Acta 61 (1997), pp. 1495-1505.

Sinninghe Damasté et al., 2009 J. S. Sinninghe Damasté, J. Ossebaar, B. Abbas, S. Schouten, and D. Verschuren, Fluxes and distribution of tetraether lipids in an equatorial African lake: Constraints on the application of the $\mathrm{TEX}_{86}$ palaeothermometer and BIT index in lacustrine settings, Geochm. Cosmochim. Acta 73 (2009), pp. 4232-4249.

Sonzogni et al., 1997 C. Sonzogni, E. Bard, F. Rostek, R. Lafont, A. Rosell-Melé, and G. Eglinton, Core-top calibration of the alkenone index vs sea surface temperature in the Indian Ocean, Deep Sea Res. II 44 (1997), pp. 1445-1460.

Sun et al., 2007 Q. Sun, G. Chu, G. Liu, S. Li, and X. Wang, Calibration of alkenone unsaturation index with growth temperature for a lacustrine species, Chrysotila lamellose (Haptophyceae), Org. Geochem. 38 (2007), pp. 1226-1234.

Teece et al., 1998 M. A. Teece, J. M. Getliff, J. W. Leftley, R. J. Parkes, and J. R. Maxwell, Microbial degradation of the marine prymnesiophyte Emiliania huxleyi under oxic and anoxic conditions as a model for early diagenesis: long chain alkadienes, alkenones and akyl alkenoates, Org. Geochem. 29 (1998), pp. 863-880.

Thiel et al., $1997 \longrightarrow$ V. Thiel, A. Jenisch, G. Landmann, A. Reimer, and W. Michaels, Unusual distributions of longchain alkenones and tetrahymanol from the highly alkaline Lake Van, Turkey, Geochim. Cosmochim. Acta 61 (1997), pp. 2053-2064.

Theissen et al., $2005 \rightarrow$ K. M. Theissen, D. A. Zinniker, J. M. Moldowan, R. B. Dunbar, and H. D. Rowe, Pronounced occurrence of long-chain alkenones and dinosterol in a 25,000-year lipid molecular fossil record from Lake Titicaca, South America, Geochim. Cosmochim. Acta 69 (2005), pp. 623-636.

Tierney et al., 2008 J. E. Tierney, J. M. Russell, Y. Huang, J. S. Sinninghe Damasté, E. C. Hopmans, and A. S. Cohen,
Northern Hemisphere controls on tropical southeast African climate during the past 60,000 years, Science 322 (5899) (2008), pp. 252-255.

Tierney and Russell, 2009 J. E. Tierney and J. M. Russell, Distributions of branched GDGTs in a tropical lake system: implications for lacustrine application of the MBT/CBT paleoproxy, Org. Geochem. 40 (2009), pp. 1032-1036.

Van Mooy et al., 2009 B. A. S. Van Mooy, Helen F. Fredricks, Byron E. Pedler, Sonya T. Dyhrman, David M. Karl, Michal Koblíek, Michael W. Lomas, Tracy J. Mincer, Lisa R. Moore, Thierry Moutin, Michael S. Rappé, and Eric A. Webb, Phytoplankton in the ocean use non-phosphorus lipids in response to phosphorus scarcity, Nature 458 (2009), pp. 69-72.

Volkman et al., $1980>$ J. K. Volkman, G. Eglinton, E. D. S. Corner, and T. E. V. Forsberg, Long-chain alkenes and alkenones in the marine coccolithophorid Emiliania huxleyi, Phytochemistry 19 (1980), pp. 2619-2622.

Volkman et al., $1988 \rightarrow$ J. K. Volkman, H. R. Burton, D. A. Everitt, and D. I. Allen, Pigment and lipid composition of algal and bacterial communities in Ace Lake, Vestfold Hills, Antarctica, Hydrobiologia 165 (1988), pp. 41-57.

Volkman et al., 1998 J. K. Volkman, S. M. Barrett, S. I. Blackburn, M. Mansour, E. L. Sikes and F. Gelin, Microbial biomarkers: A review of recent research developments, Org. Geochem. 29 (1998), pp. 1163-1179.

Weijers et al., 2007 J. W. H. Weijers, S. Schouten, J. C. van den Donker, E. C. Hopmans, and J. S. Sinninghe Damsté, Environmental controls on bacterial tetraether membrane lipid distribution in soils, Geochim. Cosmochim. Acta $\mathbf{7 1}$ (2007), pp. 703-713.

Whitehead, $1996>$ R. L. Whitehead, Groundwater atlas of the United States - Segment 8. USGS (1996).

Zink et al., 2001 K. G. Zink, D. Leythaeuser, M. Melkonian, and L. Schwark, Temperature dependency of long-chain alkenone distributions in recent to fossil limnic sediments and in lake waters, Geochim. Cosmochim. Acta 65 (2001), pp. 253-265. 